Graeme Evans and Steve Shaw work at the University of North London and are members of the Cities Research Group.

Professor Graeme Evans is Director of the Centre for Leisure and Tourism Studies. CELTS undertakes research for government, industry and international agencies, including a longitudinal study of the Jubilee Line Extension's impact on visitor activity. His new book, 'Cultural Planning: An Urban Renaissance' is now available from Routledge.

Steve Shaw

is a town and transport planner and director of the Transport Research Centre (TRaC), which recently completed a study for the DETR on social exclusion and the availability and provision of public transport. His recent co-authored book, 'Leisure and Tourism Landscapes', is also available from Routledge.

Keywords:

urban transport, leisure and tourism, urban regeneration, Jubilee Line Extension, London

Graeme Evans

Centre for Leisure and Tourism Studies,

University of North London, 166-220 Holloway Road, London N7 8DB, UK

Tel: +44 (o) 2076072789

Fax: +44 (o)20 77533240

E-mail: g.evans@unl.ac.uk

\section{Urban leisure and transport: Regeneration effects}

\section{Graeme Evans and Steve Shaw}

Received (in revised form): 12 June 2001

\begin{abstract}
The revival of leisure development in town centres and the growth of city tourism has provided a challenge for developers, operators and local authorities alike. The rationale for town-centre as opposed to out-of-town facilities is based on environmental and access/equity arguments - reducing reliance on private car usage and ownership, and locating mixed-use leisure and related facilities closer to consumers and residents. The relationship between public transport, leisure activity and urban regeneration is, however, generally underappreciated and understated, as is the phenomenon of urban tourism itself, despite the fact that in volume terms it is one of the largest elements in tourism activity in the UK. This paper discusses this relationship, with a review of leisure development, including integrated transport gateway and cultural flagship projects in European cities. The case of the Jubilee Line Extension of the London Underground is then analysed in terms of the effects that new public transport is having on visitor activity and leisure property development within an east/south-east London regeneration corridor.
\end{abstract}

\section{INTRODUCTION}

The relationship between leisure activity and transport is symbiotic, but is usually seen as benign. Transport access, whether private or public, is a prerequisite for any leisure facility beyond neighbourhood and local usage. Cruise ships, luxury coaches and some 'sightseeing' railway tours (eg the Orient Express and several 'heritage railways' in the UK, notably in national parks such as North Yorkshire and Snowdonia ${ }^{1}$ ) exploit a demand for premium travel where the journey is seen as an end in itself. Nevertheless, for the vast majority of leisure consumers, transport is seldom considered an intrinsic feature of the leisure experience. In most cases, travel is something to be endured, not a pleasure to be enjoyed. With a few notable exceptions, during the second half of the 20th century, transport facilities ceased to inspire travellers as architectural celebrations of departure and arrival. Most became places of utility - their poor image worsened by peak congestion, visible neglect and concerns over personal security. In part this is due to the disproportionate growth of mobility, for business as well as leisure, and poor maintenance of ageing public or semi-public spaces which may be hard to adapt to meet the expectations of modern travellers. On the other hand, the out-of-town leisure 
Mixed-use

(C) HENRY STEWART PUBLICATIONS 1471-549X Journal of Leisure Property VOL.1N0.4 PP $350-372$ blighted. property phenomenon has been predicated on private car usage, from the multiplex to the leisure-retail centre and theme park. When combined, since the 1980s, these factors have contributed to a decline in town and city-centre retail and leisure activity against a liberal planning regime unable to protect or attract leisure facilities and markets. This is manifested most starkly in the closure of cinemas and traditional leisure facilities (eg bowling, ice rinks, swimming baths), and in developer competition from out of town, as well as from changes in fashion and quality expectations measured in both the diversity of activities, the physical environment (eg design), and the scale of facilities on offer.

During the 1990s, the UK experienced the beginnings of a revival not only in town centres, but of mixed-use development in particular, including the rediscovery of transport facilities especially international airports, inter-city rail terminals and metro/ underground interchanges - as a value-added property and conduit for leisure development, and vice versa. This is the case in urban fringes, city centres and areas undergoing urban regeneration through leisure and visitor projects. For instance, the 'gateway' mainline railway termini around the edge of central London, once the safe possession on the Monopoly board (with a traditional if declining railway hotel attached), now serve as flagship developments as part of retail, hotel, restaurant and office developments such as Victoria Plaza, Broadgate/Liverpool Street and Paddington stations. The Broadgate development has gone even further (and see La Défense, Paris, below) with its outdoor ice rink and surrounding shops, cafes and bars, where at weekends the city workers and visitors are replaced with local people from the neighbouring borough. Two of the largest undeveloped central sites in London are on or adjoin railway lands, partly due to the availability of redundant yards and sidings. Paddington Basin is now in the process of property-led regeneration (including a proposed $183 \mathrm{~m}$-tall Grand Union Tower building by Richard Rogers), while the potential of Kings Cross/St Pancras still waits to be unlocked. Their density, high cost and 'hope' values, as well as planning restrictions and fragmented land ownership (postprivatisation), has made these sites complex and, for far too long,

British airports are of course a leisure-retail phenomenon in their own right, a talent now exported to other countries where air travel is a transitory rather than a shopping or 'visitor' experience (eg the USA). BAA (formerly British Airports Authority) has over $60,000 \mathrm{~m}^{2}$ of retail space - space which is auctioned off to retailers every three years, with BAA taking a fixed percentage of profits. As aircraft get larger, boarding and waiting times get longer, so passengers are captive shoppers for longer periods (in the jargon, 'dwell time'). Harrison, for example, has highlighted the need for building designers and retailers to understand the purchasing psychology of people on the move: transient leisure consumers who 
browse their way through airports, ferry ports, railway stations and motorway service stations. ${ }^{2}$ Airports are beginning to embrace the entertainment retailing approach to help increase such traffic, with small stages for local performers, and airport hotels are being integrated within the terminal buildings rather than in soulless hotel zones in the airport fringe area. Heathrow has four caviar shops and is the largest single outlet for Havana cigars - one in five bus passengers who arrive at these airport shopping villages do not go near an aircraft. ${ }^{3}$ Other airports are following suit: Barcelona aims to have each downtown anchor store located within the city's airport, which is now a single-level 'street' of designer shops and cafes, while the upgraded San Francisco international airport incorporates a floor of shops and restaurants with a grand ticketing hall, and a new Bay Area Rapid Transit station (see below).

\section{EUROPEAN URBAN RENAISSANCE}

In Greater Manchester, an impressive leisure-led 'renaissance' has required large-scale transport investment. In the 1970s and 1980s, decline in city-centre employment was attributed largely to traffic congestion, inadequate parking and a slow, fragmented public transport system which offered a poor alternative to the car. Too much commercial property remained vacant; out-of-town developments were a very real threat. In 1982, a feasibility study identified six corridors suitable for light rapid transit (LRT) linked at the centre by tracks along fully or semi-pedestrianised streets. ${ }^{4}$ Ten years later, Metrolink broke new ground in the UK, with LRT services to Bury and Altrincham. An extension to Eccles opened in 2000 , serving the $£ 98 \mathrm{~m}$ arts centre, The Lowry at Salford Quays (journey time from central Manchester 15 minutes), and in addition to over $£ 350 \mathrm{~m}$ in site reclamation/redevelopment, the government has pledged $£ 250 \mathrm{~m}$ towards further extensions to Oldham, Rochdale, Ashton-under-Lyne, Wythenshaw and Manchester airport. Thus the growing tram system is expected to play a key role in the regeneration of east Manchester, although timing is tight for the proposed service to the 38,000-seater stadium Sports City for the Commonwealth Games in 2002. Meanwhile, the ten-mile 'missing link' of the orbital motorway (planned nearly 50 years ago) has been completed, and despite opposition from environmentalists, Ringway Airport continues to expand as an international gateway.

Manchester - along with cities like Birmingham, Cardiff, Edinburgh and Glasgow - self-consciously positions itself as a 'European business and leisure capital', for it is on the continent that urban transport and leisure have combined to raise visitor levels and spending beyond expectations, as part of city re-imaging and place-making strategies. Barcelona, post-1992 Olympics, continues to invest in its public realm and in cultural and leisure facilities, valuing good urban design and public spaces, which have contributed to its award in 1999 (the first city to be so honoured) of the RIBA's Gold Medal for Architecture. Josep Acebillo, architect 
and former director of urban projects in Barcelona, criticised at the time the British reluctance to involve local people in regeneration projects, stating that 'if Margaret Thatcher had been mayor of Barcelona, the city's public realm would be nothing', while Barcelona's Mayor Maragall cited the fact that 'crime rates had dropped from 25 per cent to 5 per cent in ten years, whilst in ten years of law and order in London it rose one-and-a-half times' 5 This regional capital and seat of the Catalonian provincial government has served as the main business and convention centre, but now hosts more leisure than business tourists each year, in part helped by low-cost airlines making Barcelona along with Dublin two of the most popular European destinations out of London airports. In response to Barcelona and its remodelled old port area, Port Vell, ${ }^{6}$ another provincial capital, Valencia, is set to further Spain's architectural tradition with a £2bn waterside complex, the massive City of Arts and Sciences. Designed by Santiago Calatrava (his home town), this project aims to transform the dried-up bed of the River Turia where a Science Museum, a Heisphere - a planetarium shaped like the human eye - together with an ocean park, music centre and Palacio de las Artes are planned between 2001 and 2003.

Major regeneration zones also provide examples of transport-led office development linked to urban culture and the public realm. In contrast to its counterpart, London Docklands, Paris has transformed La Défense, making the Grand Arche one of the city's most visited attractions, served by a high-speed suburban railway (RER) placing La Défense, west of the centre, only four minutes from the Étoile, with new metro lines and stations and increased train capacity (double-decker) and a new TGV terminating at EuroDisney. The investment in public transport access to La Défense was also integrated with a policy of providing pedestrianised areas and facilities: 'It is enough to walk through La Défense to see that here the pedestrian is king. The esplanade has done away with the car and strolling is once again a real pleasure. ${ }^{7}$ The high degree of pedestrianisation allows a wide range of public and indoor entertainment, exhibitions, festivals and an omnimax cinema, in addition to the Grand Arche itself. Leisure retail developments are also evident in Paris, most famously I. M. Pei's Louvre extension and underground shopping plaza entrance, Carousel du Louvre. Increasingly therefore, cultural flagships are acting as the first chesspiece in a development process where other uses follow, such as Bilbao with a planned 35-storey office tower (by Cesar Pelli, designer of New York's World Financial Centre and Olympia and York's Canary Wharf tower) adjoining the Guggenheim Museum. Although La Défense was started in the 1960s and the Docklands only in the late 1970s, unlike its contemporary, La Défense was developed along carefully planned lines, using a mixture of public and private backing to generate new life. The short time span foreseen in Docklands in 1980 of ten to 15 


\section{Guggenheim 'brand'}

years contrasts with La Défense where the Établissement Public D'Aménagement de la region de La Défense (ÉPAD) was established in the mid-1960s with a 30-year life, which has been extended for a further ten years.

One of the most transformative symbols of city regeneration of the last decade has been 'Guggenheim Bilbao'. This cultural icon, costing $£ 50 \mathrm{~m}$ and designed by American Frank Gehry, has captured the imagination and the cultural tourism market, with 3.5 million visitors to date. This ultimate in branded leisure property is also being sought in cities from Rio, Shanghai and St Petersburg to Liverpool, where a Guggenheim, it is hoped, will complement the Walker Gallery as part of SOM's master plan for Port Liverpool and do for this city what the Albert Dock/Tate of the North had achieved in the 1980s. Guggenheims have recently opened in Berlin (Deutsche Bank HQ) and even in Las Vegas, casino-style, while in the home of the original museum a US\$850m proposal for a new Guggenheim (involving Gehry again) includes a library, educational facility, theatre, skating rink and a park, floating above four existing piers on Manhattan's East River: 'the museum not only as exhibition space, but as pedagogical institution and urban attraction, the old Guggenheim fused with the Rockefeller Center'. 'Bilbao babies are being born everywhere' is the comment on Gehry's interactive Experience Music Project (EMP) in Seattle. Built as a homage to local hero Jimi Hendrix, this aims to capitalise on the thousands of visitors to Hendrix's grave in Renton, south of Seattle in Washington state, as Graceland has served as the shrine to Elvis. This may ensure its viability, in contrast to the National Centre for Popular Music which languishes 'temporarily closed' only a year after opening in Sheffield, West Yorkshire, despite substantial Lottery and European funding. ${ }^{9}$ City location alone is not sufficient to generate interest - symbolic association is needed to overcome the arbitrariness of the new, as well as inherited, cultural facilities. Whether aspects of popular culture can successfully be museumified, eg sport and pop music, is also questionable when reduced to collections of artefacts, memorabilia and recordings obtainable and better experienced elsewhere. Where collections are relocated to new museums, away from their 'roots', their appeal can also suffer diminution, for example the Tower of London's Armoury collection which Leeds won with a commercially-financed 'theme museum' requiring sufficient returns from 750,000 visitors a year. Within three years annual visitors did not reach 400,000 in total (including free admissions), and with $£ 20 \mathrm{~m}$ of debts the government was forced to step in and bail out this particular regional grand projet. The unsuccessful bidder for the Armoury collection, Sheffield, would have appeared a more 'vernacular' home with its steel/metal crafts industry inheritance, and perhaps a more appropriate choice than the ill-fated pop music centre. In Britain, potential oversupply of cultural and leisure attractions through Lottery, regeneration and European Regional 
Development funding has stretched visitor markets and project viability, within an essentially unplanned system. ${ }^{10}$

Overreliance on a single brand, eg Guggenheim, also risks image decay as the brand dilutes, so as Bilbao's provincial president Josu Bergara says, apparently with no hint of irony: 'Other cities will have to find their own projects, not copies of the Guggenheim', ${ }^{11}$ and London School of Economics director Anthony Giddens spelled this out when also in Bilbao: 'Money and originality of design are not enough. You need many ingredients for big, emblematic projects to work, and one of the keys is the active support of local communities.' Consensus from the city residents was not apparent in this case, however: the imported Guggenheim concept was resisted by Basque independents and artists alike, but it was the opportunity for major infrastructure improvements and the economic development potential that such a physical and international icon would bring which convinced the regional government and which, it claims, has recouped its initial investment in the project $(£ 76 \mathrm{~m})$ and injected over $£ 300 \mathrm{~m}$ into the Bilbao economy. Bilbao's renaissance has also been facilitated by public investment in new rail, air and road systems in a planned and integrated way, and through excellent design, including a new airport terminal with a capacity for 2.5 million, designed by Calatrava; a new underground/metro running alongside both riverbanks, designed by Foster; and the Intermodal station at Abando, linking high-speed train, bus, metro and car parking, as part of a mixed-use residential and commercial development, designed by Stirling and Wilford. This lesson has been heeded in the UK with the award-winning Waterloo Eurostar Terminal (Foster), and new stations and utilities (eg ventilation shafts) on the Jubilee Line Extension which boasts a roll call of modern British design firms (see below).

In France, the second city of Lyons, which is also competing for a Guggenheim, has both the TGV network linking to Paris and an upgraded international airport, ${ }^{12}$ as is the case in Manchester, England, although the fast rail system has so far been denied this regional city. Like Manchester (eg Velodrome, Aquatic Centre, NYNEX), Lyons has sought conventions, sporting events and festivals as its main competitive city strategy, again on the back of airport, road and railway (TGV) station developments, as mirrored in Marseilles with a new TGV station serving a US\$1.2bn development of a Euromediterranee international business centre, housing and leisure complex. In Lyons the creation of new stations has also improved the fast link between both airport and city, and interchanges with the TGV service improve access and penetration of both domestic and international visitor markets (including ski charters serving the French Savoie region). The French network will allow Paris to be bypassed with a massive transport interchange - air, TGV, RER - outside of the city at Roissy, and public transport will loop around Paris with the completion of the second and third 
motorway rings, allowing more traffic to bypass the capital altogether. A triangle of these major French cities is now linked by fast TGV services within a two- to three-hour journey time from Paris.

The emerging approach to city leisure development has therefore looked to integrated transport planning and provision and mixeduse developments, including hotels, around transport gateways, and one consequence of this has been the opening up of undeveloped urban/fringe areas. In the latter case this is taking place where core visitor quarters are either saturated and/or land values have become prohibitively expensive. In the UK, the development of brownfield sites and areas in need of regeneration also accords with the Urban Task Force recommendations, ${ }^{13}$ and subsequent urban white paper (2000), with government incentives and tax breaks to encourage property development and conversion, such as accommodation above shops and pubs to converted bed and breakfast $(\mathrm{B} \& \mathrm{~B})$ usage. This policy has also sought to relieve congestion and price inflation (property and hotel rates) in visitor honeypots and historic zones, spreading visitor activity geographically more widely, with improvement in local economies, employment and land values as a result. This is arguably a more sustainable approach to development generally and to mitigating the environmental impacts from leisure and tourism in particular, including utilising off-peak transport capacity through leisure travel. Measuring the impact and relationship between urban transport and property requires a longitudinal approach, generally beyond the life of regeneration funding programmes (three to five years, eg the Single Regeneration Budget (SRB)), since the effects on local economies, land use and communities are likely to be felt over the long rather than the short term. In the USA, a good example has been a 20-year study of the Bay Area Rapid Transit (BART) system in San Francisco. This evaluation has found that the design and nature of new public transport have had a significant effect on the extent to which transport benefits can be maximised through increased passenger activity and reduced car usage, as do the efficiency and design of interchange facilities. Another finding of the evaluation of the BART network (which is still being extended) has been that the effect on land use is only really significant where supportive policy conditions, a political culture that supports public transport, local community backing and a variety of other influences were also present, creating a critical mass of facilities and activities. ${ }^{14}$

In contrast, the ancient city of Athens has long struggled with car congestion, pollution and tourism, with over 31 per cent of the national population living and an even higher proportion working in the greater metropolitan region (much higher than northern European capitals). Here, planning has been in 'crisis' due to uncontrolled land-use development (limited urban planning, zoning and protection of amenities/public realm) which has resulted in the privatisation of space and, critically, the dominance of the privateuse car. ${ }^{15}$ Until recently urban renewal has not been a particular 
policy concern of the government. In response to this inheritance, in the run-up to the 2004 Olympics, the extension and upgrading of metro and road systems for the first time attempts to link key visitor attractions and zones with business and community usage in this chaotic city. How successful this proves to be in practice remains to be seen - the International Olympic Committee has expressed serious doubts over delays in Athens' programme, and the late-20th-century experience of mega-events linked to infrastructure (often the prime rationale for their development) suggests that this is a high-risk strategy requiring a long-time horizon for the redevelopment and re-use of the event site and the payback of public investment ${ }^{16}$ (eg Expos in Montreal 1967, Lisbon 1998 and Hanover 2000, the Glasgow and Liverpool Garden Festival sites, and Greenwich Peninsula and the Millennium Dome). Two of the millennium year's major events - the Millennium Dome and Hanover Expo - both attracted less than half their projected visitors (the Dome - 4 million versus 12 million 'midi' estimate; Hanover 18 million versus 40 million) and had started to auction off their exhibits barely before they had closed. Even in the exemplar city, Barcelona (and now Sydney), Olympic sports facilities lie under-used with conflict between private and public usage, for example, of marina and boating facilities, while Manchester's Commonwealth Games facilities will require yet further public investment (as private investment and sponsorship is lacking), including the funding of a walkway link between Piccadilly mainline station and the Sports City venue.

While image and perceptual changes arising from new and improved transport are becoming evident, as the recent study of the South Yorkshire Supertram (SYS) concluded, visitor activity is still reliant upon new facilities, events and 'animation'. ${ }^{17}$ In a survey of visitors to Sheffield, the SYS was identified as the sixth most attractive development in the city (out of 13), also echoed in an exercise with local agents, but as the study's authors maintain: 'New transport investment itself is likely to have only a marginal impact on visitors or inward investment. Other promotional activities and facilities are likely to have a larger impact on selling the city than is transport.' Land use and leisure development without adequate transport access, or locating new transport systems in isolation from social amenities and other environmental investment, are both therefore unlikely to achieve sustainable regeneration objectives, as the 'unplanned' London Docklands discovered, until recent transport extensions and interchanges were completed (see below). Significantly these were completed after the London Docklands Development Corporation was wound up in 1997, in contrast to La Défense in Paris.

\section{GET OUT OF TOWN? URBAN LEISURE AND TRANSPORT}

In Britain, the response to the problematic out-of-town drift and increased private car usage has been planning policy guidance 
(PPG) aimed at town-centre revitalisation $\left(\mathrm{PPG}^{18}\right)$ and a presumption against further out-of-town development. This has been designed to revive town and district centres and to reduce traffic congestion and protect remaining green belt land. Since 1944, the south-east of England increased its urban area by 44 per cent (470,000 acres/c. 190,000 hectares), an area more than the size of Greater London itself, ${ }^{19}$ while previous governments' attempts to bring back into use derelict land in existing urban areas, through the derelict land grant scheme, had a minimal impact. From its inception in 1974 only 6 per cent of designated derelict land has been brought into use (the scheme was replaced by the Land Reclamation Fund in 1993, administered by the government regeneration agency, English Partnerships). In 1996 the last Tory government introduced the rule of 'sequential testing' into the development control process. Developers now have to prove that there is no suitable location inside a town or city before they can hope to get planning permission on a greenfield site. Most recently, mixed-use developments around transport sites have also been promoted through a revised PPG. ${ }^{20}$ This encourages councils to support high-density schemes around bus and rail stations through exercising their compulsory purchase order (CPO) powers.

Although CPO is a useful tool, in practice funding problems within local authorities have limited its application. City and town centres are again to be favoured over out of town sites, even if the latter have a transport interchange. Where significant travel and traffic is expected, developments will need to undertake a transport assessment indicating how people will travel to the site, and make improvements in public transport provision. Car-parking provision will also be limited, with leisure facilities, eg multiplex cinemas, providing up to one car parking space for five seats (the US norm, eg at sports stadia), but this may be reduced by planning authorities. Examples of large-scale mixed-use urban leisure developments include the Printworks in Manchester and Star City in Birmingham. Printworks, located in the area redeveloped following the IRA bomb in 1997, incorporates themed restaurants and bars, shops, live music arenas, a 20 -screen multiplex cinema and the first Hard Rock Cafe in the UK outside of London, while Star City is anchored around a 30 -screen Warner Village cinema, making it the largest in the UK.

In some respects the saturation of out-of-town leisure-retail developments had already seen multiplexes and other branded commercial 'leisure experiences' (eg Sony, Sega, Bass) move 'back' into town centres. The protracted development process for major leisure-retail projects has, however, seen schemes already in the pipeline extend the number of out-of-town centres into the 1990s there were more shopping centres opened in the 1990s than in the previous more liberal decade. In 1980 there was a total of 2.8 million square metres of out-of-town shopping in the UK, with 0.9 million square metres under construction; by 1988 the total had 
risen to 16 million square metres with 4 million under construction. ${ }^{21}$ Today it is estimated that 1.6 million square metres of shopping centre schemes (each covering at least $40,000 \mathrm{~m}^{2}$ ) are proposed or being developed (CB Hillier Parker, March 2001), with a further 4.15 million in the pipeline, the highest level since 1995. Although many of these schemes will not come to fruition, over 90 per cent are proposed to be located in town centres (compared with 55 per cent in 1999). A recent example is the Oracle, in Reading town centre. Built over the River Kennet, it has $70,000 \mathrm{~m}^{2}$ of shopping space, an obligatory ten-screen cinema, 23 bars and cafes, and in its first year of operation received 22 million visits. The multiplex phenomenon is, however, showing signs of peaking in its country of origin, the USA, where the number of screens increased by 22 per cent between 1997 and 2000, but cinema attendance increased by only 3 per cent, with a 10 per cent decrease in attendance in 2000 over the previous year. In the UK, cinema attendance dropped back from year-on-year growth in 1998 and, although it has recovered, it is only at the 1997 level. Small annual increases in cinema audiences and town-centre multiplex developments (at the cost of smaller cinemas, of which over 100 closed in 1999) are expected to support continued growth, but this will peak by 2004 , at which point cinema screens may reach saturation point. ${ }^{22}$ Multiplexes now represent 62 per cent of all screens in the UK $(1,710$ out of 2,758$)$, but the total number of cinema sites actually decreased in 1999. The closure of town-centre cinemas is also being reinforced by landowner/operators (eg Odeon) who are imposing restrictive covenants forbidding their use as cinemas by subsequent owners (and potential competitors). A response to the closure of smaller cinemas is seen in France, where in contrast to the more liberal UK regime, prior to the opening of a 17-screen, 3,000-seat Megarama on the outskirts of Paris, the French cultural minister announced plans to increase subsidies to small town-centre cinemas and hastily passed legislation limiting new multiplexes to 2,000 seats. With a possible oversupply in screens and the drop in cinema attendance noted above, multiplexes are also beginning to adopt more diverse programming, including arthouse films and, in multicultural areas such as Birmingham and London, dedicating several screens to Bollywood movies.

The impact from planning guidance and other market factors can be seen in a survey of leisure development planning applications received between 1996 and 1998 by all English local planning authorities (LPAs). ${ }^{23}$ Based on the response from 180 authorities (out of a total of 390 surveyed), Table 1 summarises the applications by type and location, with only 11 per cent designated as out-of-town locations as opposed to 36 per cent in town centres, 23 per cent edge of centre and 27 per cent out of centre. The urban fringe location is as important as the town centre, both in recognising the movement of populations away from the centre and into residential areas in the city periphery/inner suburbs, and in the 
Table I: Major leisure developments and their locations, 1996-1998

\begin{tabular}{lccccccc}
\hline Development type & $\begin{array}{l}\text { Town } \\
\text { centre }\end{array}$ & $\begin{array}{l}\text { Edge of } \\
\text { centre }\end{array}$ & $\begin{array}{l}\text { Out of } \\
\text { centre }\end{array}$ & $\begin{array}{l}\text { Out of } \\
\text { town }\end{array}$ & District & Unknown & Total \\
\hline Mixed leisure incl. multiplex & 22 & 19 & 10 & 3 & 1 & 0 & 55 \\
Multiplex & 15 & 8 & 9 & 5 & 0 & 0 & 37 \\
Leisure centre/pool + / health & 3 & 6 & 9 & 3 & 2 & 1 & 24 \\
Unspecified & 13 & 2 & 5 & 3 & 0 & 2 & 25 \\
Multiplex with retail & 5 & 3 & 2 & 0 & 0 & 0 & 10 \\
Health & 1 & 2 & 3 & 2 & 0 & 0 & 81 \\
A3 & 4 & 1 & 2 & 1 & 0 & 0 & 81 \\
Mixed leisure (no multiplex) & 2 & 1 & 4 & 0 & 0 & 0 & 7 \\
Stadium & 0 & 1 & 1 & 5 & 0 & 0 & 7 \\
Multiplex + sport & 1 & 2 & 2 & 1 & 0 & 0 & 6 \\
Bingo & 1 & 2 & 3 & 0 & 0 & 0 & 6 \\
A3 + Al & 2 & 1 & 2 & 0 & 0 & 0 & 5 \\
Ten-pin bowling & 3 & 0 & 1 & 0 & 0 & 0 & 41 \\
Arena & 0 & 1 & 2 & 1 & 0 & 0 & 4 \\
Night club & 1 & 0 & 2 & 0 & 0 & 0 & 3 \\
Theatre & 1 & 0 & 1 & 0 & 0 & 0 & 2 \\
Cinema & 2 & 0 & 0 & 0 & 0 & 0 & 2 \\
Total & $\mathbf{7 6}$ & $\mathbf{4 9}$ & $\mathbf{5 8}$ & $\mathbf{2 4}$ & $\mathbf{3}$ & $\mathbf{3}$ & $\mathbf{2 1 3}$ \\
\hline
\end{tabular}

Source: LPA survey $(n=180)$

consequent reduction of travel into the congested core. Of all leisure developments, 50 per cent contained a multiplex, representing 74 per cent of all town-centre leisure projects in this sample. Of the respondent LPAs, about half had policies referring to public transport accessibility for leisure sites, but over 80 per cent of London boroughs had such policies, reflecting concern for both urban density and congestion and the high level of movement into and within the capital, not least leisure travellers, represented by over 25 million tourists and 670 million day trippers a year.

This spatial shift in leisure activity has therefore been demand led (demographics and the fall in the 'youth market'), as well as planning led - notably government guidance (above) and borough unitary development plans (UDPs) with chapters devoted to 'leisure' and 'tourism', ${ }^{24}$ — with a more effective and less conflictual development process as a result. Town-centre planning and recovery strategies have also been conceptually based on a critical mass and hierarchy of retail, leisure and administrative activities, with the trend towards larger and fewer leisure facilities serving a borough or sub-region. This strategic policy has also rested on efficient access via public transport - rail/tube, bus services and, in a small but growing number of cases, tram links such as in Manchester, Sheffield and Croydon, south London. Another factor, as yet not fully reflected in the development appraisal process, is urban design quality. The influence of the Commission for Architecture and the Built Environment (CABE), jointly sponsored by the Culture and Environment ministries, is being felt within planning and design professions, as improved design is sought for public buildings and sites ${ }^{25}$ - and many town-centre leisure developments and transport schemes are public-private developments, or are on publicly owned land 


\section{4-hour city}

requiring compliance with European Commission (OJEC) procurement rules.

Leisure facilities, whether traditional recreational and cultural amenities or commercial themed projects, increasingly require good access and environmental qualities, including external design, ${ }^{26}$ image and signing, as well as internal facilities and the ability to handle visitor flows around the clock. The Star City complex in Birmingham will operate a 24-hour licence, and if the proposed relaxation of opening hours is implemented (Time for Reform white paper, May 2001), the location, planning and design of facilities will need to ensure that environmental amenity and residents' quality of life are protected. Environmental design and scale of facilities have also been found to influence directly satisfaction and repeat usage, irrespective of whether public or privately managed, ${ }^{27}$ while the range and variety of activities (and changing programmes) also influences the age range and group size (eg families with children) which leisure facilities can attract. Mono-use facilities are therefore more vulnerable to fashion and other market changes, as the multiplex and theme pub are finding with the decrease in the 15-25-year age group. The evening economy and night-time city are on the one hand promoted as a means of catering for flexible leisuretime availability and choice, and a way of extending the capacity and trade in retail and leisure facilities, and on the other as a possible way of animating towns and cities at night, improving safety and widening access for certain groups, such as women, families and older members of society. The spatial dispersion of certain leisure and cultural activities out of city centres, for example to out-of-town/urban fringe areas (eg multiplex cinemas and family entertainment centres), has in some respects undermined this strategy and in some cases made city-centre areas less safe and more dominated by younger, predominantly male, groups than previously. For instance, in a study of night-time activity in the city of Swansea, South Wales, it was found that the majority of residents (62 per cent) rarely visited the city centre in the evening, and among those that did so regularly, there was a clear sociocultural divide between activities undertaken by different participant groups. ${ }^{28}$

\section{JUBILEE LINE EXTENSION, LONDON}

In the UK, the largest single investment in public transport - at a cost of $£ 3.5 \mathrm{bn}$, and with direct effects on new and established leisure activity — has been the Jubilee Line Extension (JLE), linking central London (Baker Street, Westminster, Waterloo) with south and east London for the first time - see Map 1. First mooted in $1945,{ }^{29}$ the history and development of this Underground extension is beyond the scope of this paper, tied into a 50-year history of politics, post-industrialisation, de-urbanisation and global property development, and more. Of significance here, however, is the recognition for the first time that new public transport provision 


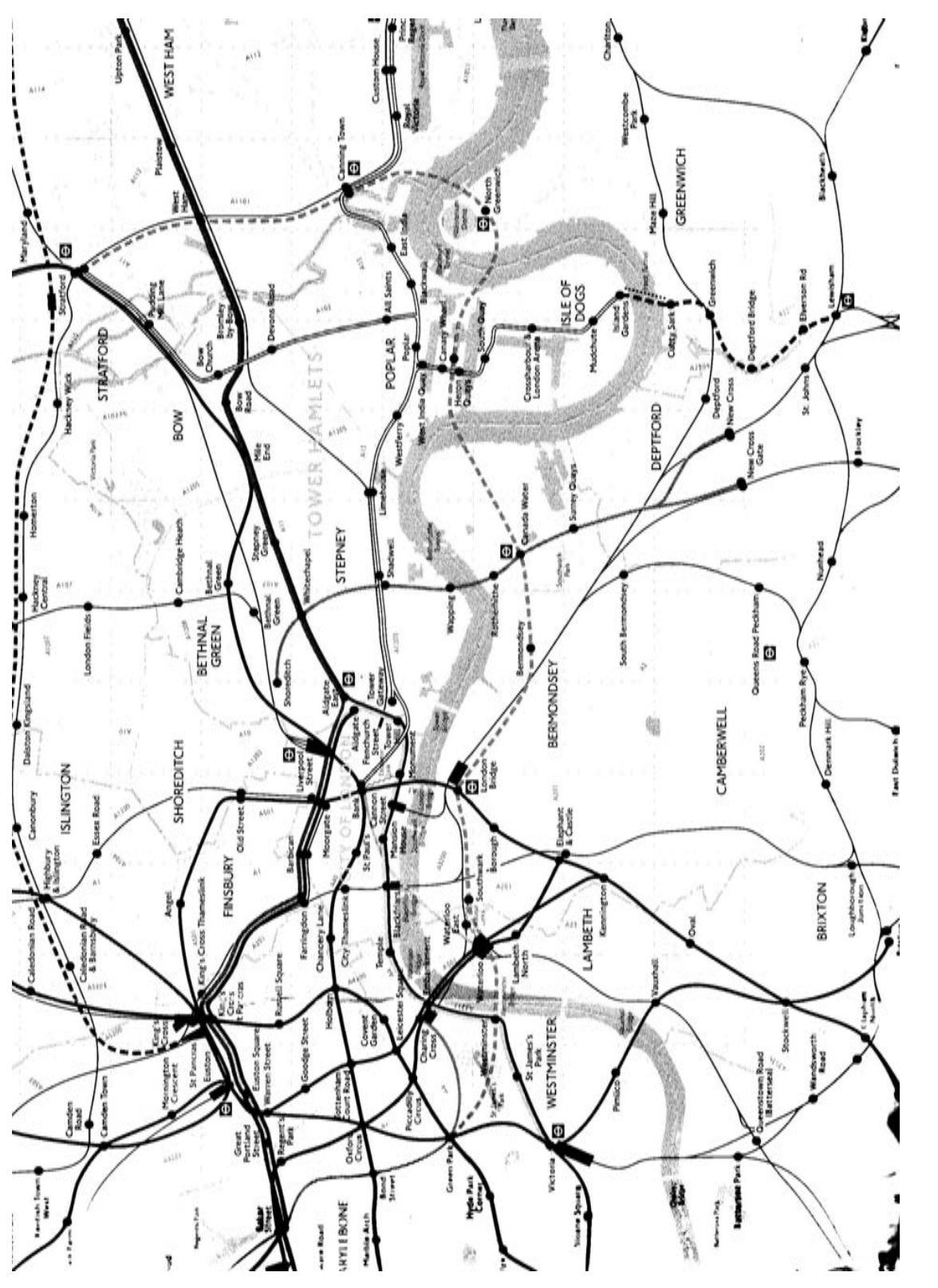

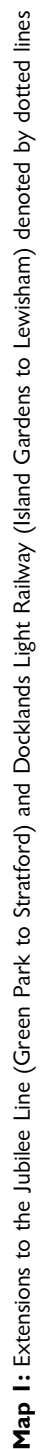


may over time have a quantifiable and sustained effect on visitor activity and leisure-related urban regeneration. ${ }^{30}$ The commissioning of separate design-led practices for both stations and other facilities also recognised the importance of urban design and quality, userfriendly environments. Signature architects included Hopkins (Westminster), MacCormac (Southwark), Ritchie (Bermondsey), Jiricna (Canada Water), Foster (Canary Wharf), Alsop (North Greenwich), van Heyningen and Haward (West Ham) and Wilkinson Eyre (Stratford). Between May and December 1999, the JLE stations finally opened, in time for the millennium celebrations and inauguration of the Millennium Dome and other cultural venues along this transformed section of the River Thames (eg Globe Theatre and Vinopolis wine museum). The JLE station 'corridor' now contains some of the most visited attractions in the UK, such as the Tate Modern and the London Eye, even excluding the temporary Millennium Dome at Greenwich, itself only accessible by serious numbers via the new JLE station at North Greenwich ( $80 \%$ of the Dome visitors travelled by tube). Hotel developments (and occupancy rates) are not surprisingly following suit. This is a critical test of addressing the central core-periphery divide in hotel and associated visitor activity in London, where property is highly concentrated, and has remained so, in a central zone and west London-Heathrow corridor. Despite planning and policy initiatives by local and central government and agencies such as the London Tourist Board, three central core boroughs (Camden, Kensington and Chelsea, and Westminster) and Heathrow (Hillingdon) host 78 per cent of all London's registered bed spaces, a proportion only 2 per cent less than in 1993 when the JLE was officially authorised by Parliament. The number of bed spaces in London has, however, increased by 8 per cent overall since 1993 , including growth in both undeveloped areas and existing tourist zones where conversion and change of use (eg from offices) has been preferred to new build. This has effectively allowed planning policy exceptions to be made in boroughs where new hotel development is otherwise discouraged. ${ }^{31}$

The background to hotel provision, distribution and capacity in Hotel provision London over the past ten years has been a perceived shortage of bed spaces overall; an over-concentration in the central core (and dearth in outer/south London), and a shortage of medium-price and budget-range accommodation. ${ }^{32}$ London has had a persistent reputation as an expensive, poor-value (quality and price) destination in contrast to other European cities, while other factors, such as the loss of $\mathrm{B} \& \mathrm{~B}$ accommodation for social service usage, have exacerbated these problems. The established regional policy and strategic plans promoted by both the tourist board and planning agencies have been to improve quality and value for money (eg training/skills, classification/grading system, use of Information and Communication Technology (ICT) etc), to encourage hotel development in outer London and away from the 
central core/Heathrow corridor, and to increase $\mathrm{B} \& \mathrm{~B}$ accommodation through the relaxation of planning regulations, fire and safety restrictions and rating. ${ }^{33}$ The JLE corridor and surrounding east London regeneration areas potentially serve these policy objectives, including the employment possibilities raised through local economic development and more sustainable development of tourism over a wider area.

While the total number of bed spaces provides the main measure of hotel provision, the scale of hotels/B\&Bs is also important in the same way that flagship attractions have a disproportionate effect on visitor activity, carrying capacity and the image of the area in which they are situated. Larger hotels also tend to have more and higherquality amenities such as conference suites, leisure (eg health and fitness) and shopping facilities, attracting a different category of visitor and a higher employment/expenditure multiplier than smaller, more isolated establishments. Table 2 summarises for London as a whole the breakdown of establishments by size, with decreases in recent years occurring in those with under 50 rooms, and during the 1990 s increases at both the top and the very bottom ends of the scale. The high occupancy levels driving four- and five-star hotel development (annual average of 82 per cent) is contrasted with small accommodation providers such as B\&Bs with 60 per cent, although even this is much higher than the average occupancy rate in Europe: London hotels have the highest room yields, despite their perceived poor value and high cost. The rapid growth of branded budget hotels with higher room capacity (eg Travel Inn, Travel Lodge, Holiday Inn) is also starting to impact outside of motorway and other intransit locations, and with reported occupancy levels of 90 per cent in the UK, these are now opening in lower land-value locations and in regeneration areas, including the JLE corridor (eg Ibis Stratford, Canary Wharf; Holiday Inn Express - North Greenwich, Canada Water, Southwark; Forte Posthouse - Canary Wharf; Travelodge - Canning Town). However, as Harris points out, in contrast to the UK: 'Another strong element which has contributed to the growth in the budget [hotel] sector in both France and the USA is the level and quality of internal transportation systems. If these are insufficient, people will not be encouraged to travel. ${ }^{34}$

Table 2: London stock of serviced accommodation, 1993-1999

\begin{tabular}{lrrrrrrrr}
\hline $\begin{array}{l}\text { No. of } \\
\text { bedrooms }\end{array}$ & $\mathbf{1 9 9 3}$ & $\mathbf{1 9 9 4}$ & $\mathbf{1 9 9 5}$ & $\mathbf{1 9 9 6}$ & $\mathbf{1 9 9 7}$ & $\mathbf{1 9 9 8}$ & $\mathbf{1 9 9 9}$ & $\begin{array}{l}\text { \% change } \\
\mathbf{1 9 9 3 -} \mathbf{9 9 9}\end{array}$ \\
\hline $201+$ & 85 & 88 & 90 & 90 & 95 & 95 & 96 & +13 \\
$101-200$ & 84 & 84 & 85 & 84 & 91 & 95 & 99 & +18 \\
$51-100$ & 139 & 127 & 123 & 134 & 135 & 132 & 138 & -1 \\
$26-50$ & 206 & 185 & 183 & 184 & 198 & 199 & 208 & +1 \\
$11-25$ & 379 & 299 & 283 & 271 & 278 & 281 & 289 & -24 \\
$4-10$ & 216 & 135 & 122 & 125 & 127 & 131 & 142 & -34 \\
$1-3$ & 132 & 89 & 74 & 72 & 101 & 121 & 182 & +38 \\
Total & $\mathbf{1 , 2 4 1}$ & $\mathbf{I , 0 0 7}$ & $\mathbf{9 6 0}$ & $\mathbf{9 6 0}$ & $\mathbf{I , 0 2 5}$ & $\mathbf{I , 0 5 4}$ & $\mathbf{1 , \mathbf { 1 5 4 }}$ & $\mathbf{- 7}$ \\
\hline
\end{tabular}

Source: LTB (1997) Tourism Strategy for London and Action Plan 1997-2000. Annual London Tourism Statistics 
Hotel developments - new and upgrades - have therefore started to take place in less developed areas served by the JLE and other public transport facilities (notably the Docklands Light Railway (DLR) extension south to Greenwich and Lewisham - see Map 1). Increases in bedstock in the riparian boroughs are apparent in Southwark - up 30-38 per cent between 1993 and 1998 - and Lambeth, where provision has trebled, while Greenwich has increased its hotel capacity by 50 per cent since 1996 and Tower Hamlets by 60 per cent since 1993. In the boroughs in which JLE stations are located, the number of bed spaces increased by a total of 37 per cent over this period compared with less than 13 per cent for London as a whole. In the JLE corridor measured by a $1 \mathrm{~km}$ catchment area around each station (see Map 2) - the number of hotels has more than doubled since 1993. This has included chains (eg Ibis) and independent hotels, initially serving as cheaper 'overspill' for central venues running at capacity, but increasingly these are seeing 'residential' usage with tourists opting to stay in these areas, not just come on day trips from the traditional hotel zones in central/west London to historic areas of maritime Greenwich/town centre and Bankside, Southwark. This reflects not just the presence of a range of leisure and cultural attractions and amenities such as restaurants, parks and street markets - an important mix for urban tourism - but the marketing of these destinations and investment in the public realm by local authorities, regeneration partnerships (eg several SRBs/City Challenge areas - Cross River, Pool of London, Creekside, Deptford) and the private sector. Initiatives such as the South Bank Employers' Group, Bankside Trust and town-centre management consortia have demonstrated that property led regeneration alone is not sufficient to put and keep areas on the map, as noted above, but also requires the 'soft infrastructure' of joint destination area marketing and promotion, building/area conservation, and training programmes to facilitate local employment and service quality. ${ }^{35}$

\section{Visitor attractions}

The second indicator of the effect of new transport on leisure development activity is the number of visitors attending individual attractions and zones in the JLE corridor. This has been measured from an audit and mapping of facilities in the pre-JLE period (1993), before JLE opening (1998) and initial opening points (1999). ${ }^{36}$ Visitor numbers are, however, an understatement, to the extent that some activity is not measured and open or uncontrolled areas seldom have verifiable visitor data. Surveys of visitors to street markets, for instance, suggest that they are major attractions in their own right, eg Greenwich crafts market attracts 50,000 each weekend, ${ }^{37}$ Camden Lock and adjoining markets attract nearer 100,000. This particularly affects the Canary Wharf catchment (eg London Arena, Canary Wharf tower, free events etc) and open/ street-market activity along the South Bank and Bermondsey, and 


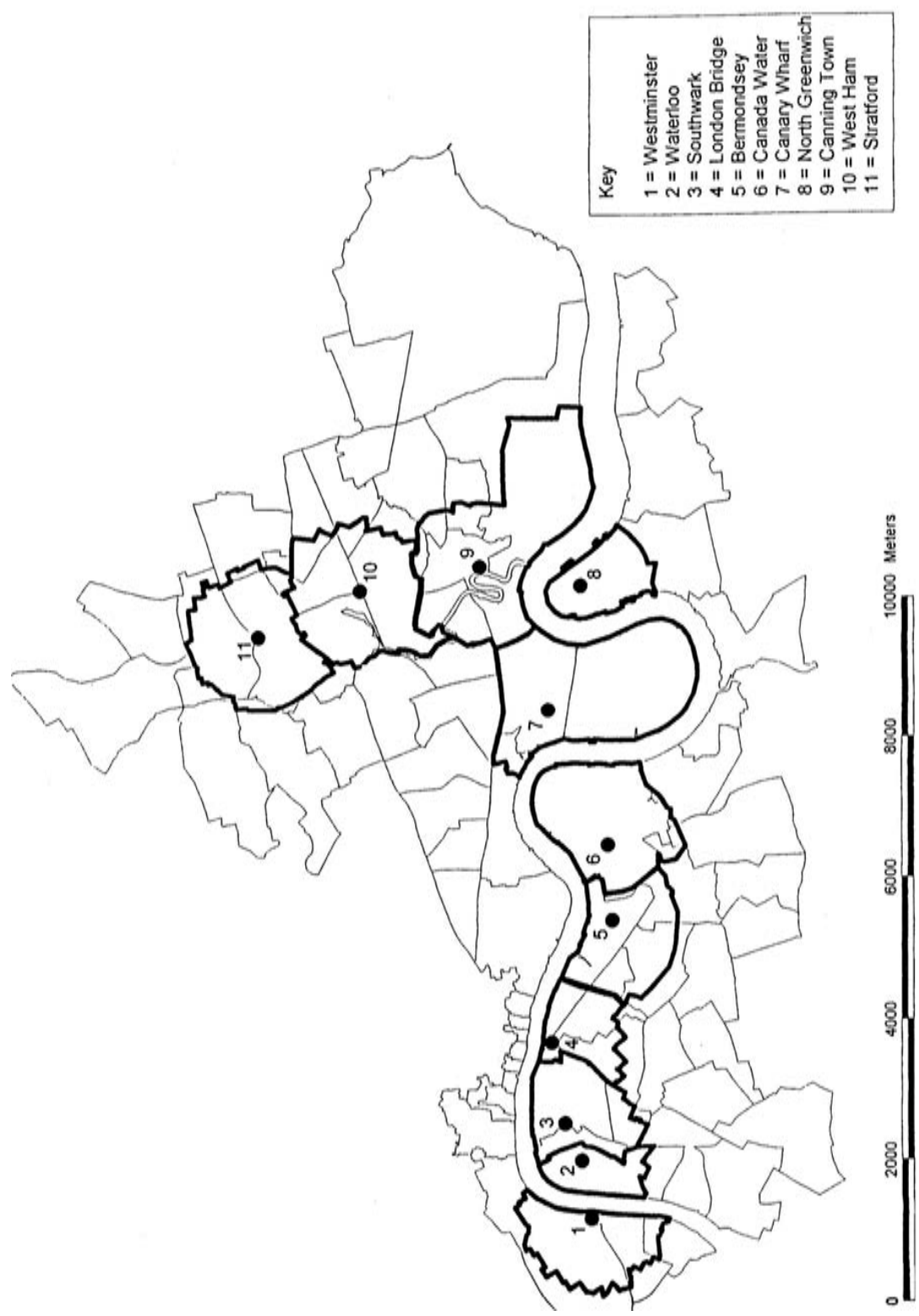


around Stratford town centre and developing cultural quarter (independent cinema, theatres). The authors estimate that the total number of visitors is actually around 10 per cent above the declared figures (Docklands surveys estimated 1.5 million leisure visits in 1996), making this a conservative assessment. Table 3 summarises the number of visitors to attractions in each station catchment from 1993 to 1999 and shows estimates for 2000, taking the 1993 base and then all attractions (ie those existing at the 1993 base point and those opening after 1993). In overall volume terms, visits to attractions already established by 1993 in the JLE corridor increased by over 20 per cent, from nearly 14 million in 1993 to 19 million in 1999, while after including new attractions opening since 1993, this level increases to over 29 million in 2000, or 25 million without the Dome at Greenwich. Even without the Dome effect, visits to attractions opening since the JLE approval in 1993 totalled over 8 million in 2000, representing nearly one-third of total visits in the JLE corridor. This increase - which is both supply led, ie new/improved attractions and transport access (over 90 per cent of overseas tourists to London use the Underground, compared to 50 per cent buses and 30 per cent taxis), and demand led, as tourist arrivals in London during the 1990s recorded year-on-year growth - is most marked in Southwark where visits trebled, and London Bridge where they have doubled, but also shows a 20 per cent increase even in the well-established tourist zones of Westminster and Waterloo. Underlying growth in tourist arrivals has of course contributed to this scenario, but a 56 per cent increase in tourists to London as a whole between 1993 and 2000 is far exceeded in the JLE corridor with an 80 per cent increase over the same period. This reflects both real-term growth in visitor activity and in some cases a switching effect between attractions and locations, most notably the Tate Modern gallery and cultural quarter at Bankside, at the cost of the original, more isolated Tate Britain gallery at Millbank, where attendances have declined since its sister gallery opened in May 2000.

While the cultural quarter of Bankside and office city of Canary Wharf, Docklands have both benefited from the tube extension and interchange with other transport lines (East London main line, DLR), station catchments which are likely to see latent leisure and other property development (eg offices and residential) include Bermondsey and, further east, Canning Town, West Ham and Stratford, the current eastern end of the JLE and proposed Channel Tunnel rail link terminus (CTRL). In Bermondsey, previously not served by an Underground station, a new fashion museum is under construction, housing Zandra Rhodes's collection. A single specialist attraction may not on its own establish regular visitor activity, but by putting an unknown area on the map for the first time, ancillary facilities (eg cafes/restaurants) are already moving in and others will follow. London has a high repeat tourist profile, and these visitors therefore look for both new and more unusual 
Table 3: Aggregate visits to attractions in the JLE corridor, 1993-2000 (000s)

\begin{tabular}{|c|c|c|c|c|c|c|c|c|c|}
\hline Station & 1993 & 1994 & 1995 & 1996 & 1997 & 1998 & 1999 & $\begin{array}{l}2000 \\
\text { (est.) }\end{array}$ & $\begin{array}{l}\text { \% change } \\
1993-2000\end{array}$ \\
\hline Westminster & 7,632 & 8,274 & 8,308 & 9,032 & 9,006 & 9,673 & 9,859 & 10,174 & 33 \\
\hline Waterloo & 4,438 & 4,429 & 4,425 & 4,488 & 5,233 & 5,294 & 5,827 & 8,782 & 188 \\
\hline Southwark & 864 & 932 & 927 & 2,066 & 2,114 & 2,471 & 2,262 & 3,891 & 350 \\
\hline London Bridge & 886 & 1,365 & 1,519 & 1,540 & 1,566 & 1,582 & 1,743 & 2,165 & 144 \\
\hline Bermondsey & 129 & 107 & 121 & 128 & 169 & 161 & 149 & 149 & 16 \\
\hline Canada Water & $\mathrm{N} / \mathrm{D}$ & $\mathrm{N} / \mathrm{D}$ & $N / D$ & $N / D$ & 4 & 14 & 15 & 7 & - \\
\hline Canary Wharf & $\mathrm{N} / \mathrm{D}$ & $N / D$ & $N / D$ & $\mathrm{~N} / \mathrm{D}$ & $N / D$ & $\mathrm{~N} / \mathrm{D}$ & $N / D$ & 100 & - \\
\hline North Greenwich & 0 & 0 & 0 & 0 & 0 & 0 & 0 & 6,500 & - \\
\hline Canning Town & 0 & 0 & 0 & 0 & 0 & 0 & 0 & 0 & - \\
\hline West Ham & 21 & 21 & 21 & 26 & 26 & 31 & 31 & 31 & 48 \\
\hline Stratford & $\mathrm{N} / \mathrm{D}$ & $N / D$ & $N / D$ & 82 & 82 & 0 & 0 & 0 & - \\
\hline Total & $|3,97|$ & 15,128 & 15,322 & $|7,36|$ & 18,200 & 19,227 & 19,888 & 31,800 & I 20 (8I ex-Dome) \\
\hline$\%$ annual change & - & 8 & 0.7 & 13 & 5 & 6 & 3 & 55 (27 ex-Dome) & \\
\hline Total 1993 baseline & $|3,97|$ & 15,077 & 15,176 & 15,915 & 15,862 & 16,505 & 16,403 & 17,016 & 18 \\
\hline Additional & - & 51 & 146 & 1,446 & 2,338 & 2,772 & 3,485 & 14,784 & \\
\hline
\end{tabular}

Note: 1993 baseline total includes visitor attractions already open in 1993 prior to the JLE 'go ahead' by Parliament. N/D - No data.

Leisure transport areas and attractions outside of the main tourist sites and zones. Further east, Canning Town provides a short bus and taxi link to both City airport and the new ExCel exhibition centre at the Royal Docks, operated by the NEC group and now third in capacity to Earls Court/Olympia and the NEC Birmingham. ExCel's planning brief was based on the principle that 55 per cent of visitors would arrive by public transport, and visitor levels could reach 42,000 a day. ${ }^{38}$ These local areas had little or no leisure or visitor facilities before and could not hope to attract or sustain significant visitor numbers or investment (eg employers, office premises) without the new public transport. Public transport access is also two-way: local residents gain more efficient access to other parts of the city for employment and leisure, an important factor since these areas tend to have relatively higher unemployment and poorer amenities.

New transport links can also divert leisure visitors away from local and non-leisure traffic, reducing congestion and conflict. For instance, the new station at Cutty Sark Gardens, Greenwich on the DLR extension was at first resisted by the line's operators and some local residents/traders - this extension was to be privately financed from incremental passenger revenue (and a ticket premium) and the existing mainline station at Greenwich was felt to be adequate to cater for regular commuters as well as tourist traffic (the town receives over 2 million visitors, largely day visitors, a year). The environmental disaster this would entail in a historic town with narrow pavements and heavy road traffic, as thousands converge from the old station on the visitor zone (Cutty Sark, Maritime Museum, Royal Park and Observatory) was finally recognised, ${ }^{39}$ but it was the potential of a new station, as part of a mixed-use maritime visitor centre, riverside complex and proposed cruise ship terminal, and additional transport revenue, that made feasible a $£ 14 \mathrm{~m}$ station development on this line, which now serves as a leisure travel experience in its own right. The DLR extension 
and switch to off-peak leisure usage, together with new developments coming onstream, have also compensated for the loss of commuter passenger traffic from the existing DLR line to the new JLE, along the Bank-Canary Wharf-Stratford corridor, against pessimistic predictions of a net decrease of between 30 per cent and 40 per cent in passengers on the DLR system. The operators of the DLR are working with developers and the local authority to improve access to the line. For example, at Heron Quay, where a major extension to Canary Wharf is under construction, the station is to be roofed over and an escalator link built to a shopping mall that will give covered access to the Jubilee Line at Canary Wharf.

To date, there has been an increase of two-thirds in the number of visitor facilities - accommodation and attractions - in the JLE corridor between those existing prior to 1993 and those opened or due to open after 1998, with half of these opening between 1993 and 1998, ie before the JLE went 'online'. The largest change was in hotels, albeit from a low base of 14 pre-1993, to 32 in 1999; in entertainment and exhibition venues, which increased from 14 to 24 over this period; and attractions and museums, up from 31 to 49. In terms of the distribution of these new facilities in the corridor, the South Bank/Bankside area saw a 50 per cent increase in facilities overall, served by Waterloo, Southwark and London Bridge stations, while in Canary Wharf they doubled from a low base, mainly by increases in the number of hotels. The number of facilities also increased in Stratford, from one to six. Visitor attractions and hotels due to open from 2000 onwards will increase the level and scale of amenities. This will take place not just in the touristic zones of Westminster and Bankside, but post-Millennium Dome in and around the Greenwich peninsula, and also with the build-up around Canning Town/City airport and Stratford town, as a critical mass of activity and development moves eastwards.

\section{CONCLUSION}

Urban leisure and transport development is going through a new and mutually reliant phase, not yet on the scale of Europe, but if Labour manifesto commitments are implemented, new strategic projects (eg east-west Cross Rail, £2.5bn; DLR spur to City airport, $£ 30 \mathrm{~m}$ ) will further improve London's position compared with its European city competitors. The DLR spur, for instance, is to be funded by central government, City airport, the London Development Agency and developers and builders, and such cofunding arrangements indicate the recognition that urban transport directly contributes to the regeneration and development process.

Off-peak leisure travel generates revenue for transport operators and can maintain the viability of some routes (eg DLR). Areas in post-industrial decline looking to create major leisure/cultural facilities require accessible public transport in order to assist the regeneration process, sustain visitor activity and attract local as well as tourist usage. Attributing leisure activity and development to 
public transport provision directly is complex, hard to place a value on, and in the urban situation is often only part of the story. Other factors aside from the market include the image and quality of the leisure attraction and facility itself; a critical mass of facilities and amenities; marketing and promotion, including joint marketing initiatives targeting leisure passengers; and linking transport with venues through ticketing and information (eg maps, guides). Many cities in Europe (eg Paris, Gothenberg) now operate museum cards which cover public transport use, while some cities better exploit their river and surface transport as part of the visitor experience itself. It would be hard to imagine the new Tate Modern sustaining its first year's 5.25 million visitors without the upgrading and opening of new underground stations, while the Greenwich peninsula post-Dome will likewise eventually rely on its new tube link to central London, a source of Canary Wharf's new-found confidence. ${ }^{40}$ The impact on less-developed areas of the JLE corridor will take longer, as the BART experience in San Francisco attests.

However, the development of branded and independent hotels and medium-scale visitor attractions in areas previously devoid of both suggests that integrating leisure with transport is a strategy required to widen both the volume and distribution of leisure activity, and one which any environmental impact and cost-benefit analysis of new public transport investment needs to take into account more fully. This may not be limited to the medium scale with the Wembley Stadium development stalled yet again, Stratford is proposed as 'the perfect site for a national arena' according to Sir Peter Hall, ${ }^{41}$ who in the 1960 s was one of the academic 'architects' of the London Docklands Development Corporation, closely associated with the reactive "non-planning" ${ }^{42}$ approach to urban development. Good public transport access and interchanges, rather than single or non-integrated provision, may well facilitate this, as the multi-mode transport systems serving major leisure complexes in Europe suggest. This demands an integrated transport and strategic planning approach to urban regeneration, beyond the limited time horizons of both political and development cycles, and as Ashworth concluded:

\section{'Urban tourism requires the development of a coherent body of theories, concepts, techniques and methods of analysis which allow comparable studies to contribute towards some common goal of understanding of either the particular role of cities within tourism or the place of tourism within the form and function of cities. ${ }^{34}$}

The JLE impact study has been established by London transport authorities in order to assess the effects of major public investment over the longer term, and for the first time this includes the effects on leisure and tourism activity and related development. It is 
obviously too early to quantify or attribute these effects, but the evidence to date suggests that this interrelationship is significant and one which the series of planned 'after' impact studies will start to measure. The exercise will hopefully contribute to improved transport investment appraisal and development planning in the future.

\section{References}

1. Matthews, B. and Beswick, A. (1999) 'Balancing impacts - The case of heritage railways in the UK', Optimising Tourism Impacts Conference, University of Westminster, London, December.

2. Harrison, J. (1996) 'Airport retailing: A view of the future', Airport Forum, April, pp. $41-44$.

3. Evans, G. L. (1998) 'Urban leisure: Edge city and the new pleasure periphery', in Collins, M. and Cooper, I. (Eds) Leisure Management - Issues and Application, Wallingford, CAB International, pp. 113-138.

4. Shaw, S. (1993) Transport: Strategy and Policy, Oxford, Blackwell, p. 193.

5. Fairs, M. (1999) 'Spanish let fly - Barcelona's Royal Gold Medal Winners use RIBA ceremony to deliver broadside at neglect of Britain's cities', Building Design, 25 June, p. 1.

6. Sastre, J. M-M. (1993) 'Remodelling of the Old Port of Barcelona', in Bruttomesco, R. (Ed) Waterfronts - A New Frontier for Cities on Water, International Centre for Cities on Water, Venice, pp. 58-62.

7. EPAD (1993) La Défense, Point Info-Service Communication, Paris, Établissement Public de Aménagement de la Region de La Défense.

8. Ryan, R. (2000) 'New frontiers', Tate, Tate Modern Special Issue, No. 21, pp. 90-96.

9. Evans, G. L. and Foord, J. (2000) 'European funding of culture: Promoting common culture or regional growth?', Cultural Trends, No. 36, pp. 53-87.

10. Evans, G. L. (1995) 'The National Lottery: Planning for leisure or pay up and play the game?', Leisure Studies Journal, Vol. 14, No. 4, pp. 225-244.

11. Crawford, L. (2001) 'Bilbao thrives from the "Guggenheim effect"', Financial Times Weekend, 28 April, p. 2.

12. Tesse, P-Y. (1993) 'The importance of European airports in the development of urban tourism: The impact of the TGV junction, Lyon', International Conference on the Urban Environment: Tourism, September, South Bank University.

13. DETR (1999) An Urban Renaissance. Final Report of the Urban Task Force, London, Department for the Environment, Transport and the Regions, Routledge.

14. Cervero, R. and Landis, J. (1997) 'Twenty years of the Bay Area Rapid Transit System: Land use and development impacts', Transport Research, Part A, Vol. 31, No. 4, pp. 309-333.

15. Deffner, A. (1993) 'Cultural activities in Greece: Tradition or modernity? (Geographical distribution of cultural spaces in Greece)', paper presented to the Leisure Studies Association, Third International Conference, Leisure in Different Worlds, Loughborough University, July.

16. Evans, G. L. (1996) 'Planning for the British millennium festival: Establishing the visitor baseline and a framework for forecasting', Journal of Festival Management and Event Tourism, No. 3, pp. 183-196.

17. Lawless, P. and Gore, T. (1999) 'Urban regeneration and transport investment: A case study of Sheffield 1992-96', Urban Studies, Vol. 36, No. 3, pp. 527-545.

18. DoE (1993) Planning Policy Guidance 6, Town Centres and Retail Development, London, Department of the Environment.

19. CPRE (1993) The Lost Land, London, Council for the Protection of Rural England.

20. DETR (2001) Planning Policy Guidance Note 13 (revised) Transport, London, Department of the Environment, Transport and the Regions.

21. Evans, ref. 3 
22. LIRC (2000) Leisure Forecasts 2000-2005, Sheffield, Leisure Industry Research Centre.

23. The Tourism Co (2001) Research Report on Planning for Leisure and Tourism, London, DETR.

24. Evans, G. L. (2000) 'Planning for urban tourism: A critique of borough development plans and tourism policy in London', International Journal of Tourism Research, Vol. 2, No. 4, pp. 1-20.

25. DETR (2000) By Design — Urban Design in the Planning Systems: Towards Better Practice, London, CABE/DETR.

26. CABE (2001) The Value of Urban Design, London, Commission for Architecture and the Built Environment.

27. Craig, S. (1991) Customer Service Audit of Leisure Facilities, London, Leisure Futures.

28. Thomas, C. J. and Bromley, D. F. (2000) 'City-centre revitalisation: Problems of fragmentation and fear in the evening and night-time city', Urban Studies, Vol. 37, No. 8, pp. 1403-1429.

29. Horne, M. C. (2000) The Jubilee Line: An Illustrated History, London, Capital Transport Publishing.

30. Evans, G. L. and Shaw, S. (1999) 'Urban tourism and transport planning: Case of the Jubilee Line Extension and East London corridor', RGS/IBG Symposium, British Tourism: The Geographical Research Frontier, University of Exeter, September.

31. Evans, ref. 24.

32. LTB (1997) Tourism Strategy for London and Action Plan 1997-2000, London, Joint London Tourism Forum.

33. Tourism Concern (1999) The Participation of Local Communities in Tourism; A Study of Bed \& Breakfast in Private Homes in London, London, Tourism Concern.

34. Harris, S. (2001) 'Comment: The future of the European branded budget hotel sector', Journal of Leisure Property, Vol. 1, No. 2, pp. 113-118.

35. CELTS (1998) Leisure Industries Training Strategy, Focus Central London TEC, Centre for Leisure and Tourism Studies.

36. CELTS (2000) Visitor Activity Study of the Jubilee Line Extension, Working Paper No. 37, JLE Impact Study Unit, University of Westminster, London.

37. Evans, G. L. (1994) Cutty Sark 2000 - Visitor Validation and Forecast for Greenwich Town 1995-2010, London, Greenwich Waterfront Development Partnership.

38. Abbot, J. (2001) 'Docklands just goes on growing', Modern Railways, April, pp. 29-34.

39. Evans, ref. 37

40. Lynn, M. (2001) 'Born again city', Management Today, June, pp. 54-65.

41. Hall, P. (2001) 'Stratford is the perfect site for national arena', Regeneration and Renewal, 11 May, p. 12.

42. Barker, P. (1999) 'Non-plan revisited: Or how cities really grow', Journal of Design History No. 12, pp. 95-110.

43. Ashworth, G. (1992) 'Is there an urban tourism?' Tourism Recreation Research, Vol. 17, No. 2, pp. 3-8. 